Arbnora Dushi

\title{
FOLKLORISTICS AND THE CHALLENGES OF DEFINING ITS DISCIPLINE: THE RELATION OF FOLKLORISTICS AND ORAL HISTORY
}

\begin{abstract}
For two centuries folklorists around the world have attempted to define the boundaries of their discipline but their efforts have never been considered complete. There are even some who have given up considering that the "definition of folkloristics is not really necessary" (Elliot Oring). But there are also many disciplines that were born out of folkloristics and developed in other directions, enabling the illumination of other aspects of this matter.

In my paper I will see the relation of folkloristics with oral history, which in many respects meet but differ in the concept and methodology of research. What connects folklore and history? Where are the differences and similarities between these two disciplines?

Oral history is a practice and it is a research method which in recent decades is finding application in many areas of life practice, but also in many social sciences. By oral history we refer to the act of recording the words of people who have something interesting to say, recording their memories of a past event and then analyzing these materials (Lyn Abrams). Memory and storytelling connect history with folklore, which further develop to the oral history. The presence of the research subject often brings closer folklore to oral history but concepts and methodologies differentiate their approaches to the same matter. In this paper we will address this relation, looking at the research practice, as well. I will base my research on the research publications of Dan Ben-Amos, Richard Dorson, Jan Vansina, Alessandro Portelli, Lyn Abrams and others.
\end{abstract}

Keywords: Folkloristics, oral History, oral Narrative, life Story, memory.

\section{Challenges of Folkloristics: some examples from international schoolarships}

Dan Ben-Amos, author of the well-known article "Toward definition of folklore in context" (Ben-Amos, 1971), in a review that he made later (Ben-Amos, 1983) which was based on previous article about defining folklore, considers that the primary features of folklore in a confrontation with new changes, cannot be accepted by the modern man. According to him, the attributes that dominated concept of folklore for many years, like traditionality, irrationality, rurality, communality, orality, anonymity etc. cannot incude new folk genres that are result of a new way of living (Ben-Amos, 1983, 11-17).

Similar existential dilemmas for the discipline that preoccupied folklorists since the second half of the twentieth century, when industrialism penetrated many spheres of life meant that archaic forms of folklore were "contaminated" by modernity. More than forty years ago (1972) Richard Dorson stated that "in a few years there will be no more folklore, and science will no longer need folklorists" 
(Dorson as cited by Blank, 2009, 1). One such concern was expressed by Dan BenAmos himself, who said that "if there are the initial suspicions for subject of folklore that is heading towards extinction, then it's possible for its science to follow the same path" (Ben-Amos, 1983, 13). In such a situation, folklorists had to make a choice. There is the example from Finland. The members of Finnish school of folkloristics, in the period of industrialization, seeing that the folk world of the Finns is going to be "modified" by the influences of new technological opportunities, were organized among themselves to discuss about the status of folkloristics. On this occasion, Maatti Kuusi, was head of the Department of Folklore at the University of Helsinki, proposed that national folklore studies should focus on comparative studies, thus opening up opportunities to study the folklore of other peoples in line with the Finnish one. Also pop culture, mass media and Internet, as well as youth culture, should be included as parts of the research of folklore (Hakamies, 2003, 6-9). There is also the example from Slovenian folkloristic, when the conceptual boundaries of national folkloristic were not "fit" for materials from the fieldwork. Facing new methodological trends, folklore scholars were faced with the dilemma "What to do with folklore?", as stated in the article of Slovenian ethnomusicologist Zmaga Kumer. Such a definition that characterized folklore as the traditional culture of uneducated people as in conflict with social progress (Golež Kaučič, 2017, 4-9). This kind of experience has been followed by scholars of folkloristics in many countries of Europe and the region, where the confronting developments on the ground with outdated folklore methods has led folklorists to think of modifications or enhancements to the discipline's definition. Some have been able to overcome and adapt to change, but there are other schools that continue to face such challenges.

Two folklorists from the Ohio State University, Martha Sims and Martine Stephens, were aware for the need of redifining the boundaries of the folklore, seeing the continued emergence of new concepts for folklore settings. Their book "Living Folklore" was soon embraced by school curricula. Its applicability is very present today in many academic studies of folklore. So, according to them, folklore is not a fiction, it is not an unrealistic thing found only in fairytales, as it is not another form of anthropology or literature, as we were used to acknowledge. Folklore is neither an elite nor a folk culture; rather, it is our informal and nonformal learning of life that we accept daily, in the family, from generations, and we, more or less, express it artistically through words, actions, behavior. The authors give the definition that:

Folklore is informally learned, unofficial knowledge about the world, ourselves, our communities, our beliefs, our cultures and our traditions, that is expressed creatively through words, music, customs, actions, behaviors and materials. It is also the interactive, dynamic process of creating, communicating, and performing as we share that knowledge with other people

(Sims \& Stephens, 2005, 8). 
Such a widespread extension of the concept of folklore, gradually justified and elaborated by theorists of this science decades ago, has been witnessed by folklorists during their work on recording folklore. So, we see that the definition of folklore has changed since it was coined as a term by William Thoms in 1846. Thus, redefining folklore is a constant requirement of time and the development of academic theories should go hand in hand with developments in the fieldwork.

\section{Folklore between memory and testimony}

Recordings of oral prose and narratives, of the consolidated genres such as fairytales and anecdotes, confronted folklorists in the field with another type of narratives that were not initially considered folklore. There were these stories from personal life experiences, real life stories, that people wanted to tell, in the style of $I$ don't remember any fairytale but I can tell you what happened to me once ...or Instead of an anecdote I will tell you what happened to my mother last year ... ! These narratives were based on personal experiences and were not connected to any traditional genre, neither any transmitted narratives nor they were inherited from past generations.

What connects these kinds of narratives with folklore? How folklorists have considered them? Folklore collectors, in almost all academic schools recorded these units while including them in the category of memory narratives (memorates). But initially they did not elaborate them, because they believed that the elements of the real happenings present within these narratives, removes them from considering parts of folklore. (Heimo, 2001, 153). This was due that the given definition of folklore was narrow. The fictional element, the fantasy and imagination were the dominant aesthetic categories that characterized a folk creation. In addition to excluding the presence of the real (the truth), the folklore definition as well did not accept the concept of the individual and the personal, meaning expression of the personal world (Dushi, 2015, 91-98). Traditionality, anonymity, communality that were considered general attributes of folklore (Ben-Amos, 1983, 12), excludes from folklore these units whose authorship was known.

All the creators, respectively the performers, were seen as transmitters of an inherited tradition, which passed from one generation to the next and their individual authorship was unnoticeable. Vladimir Propp also addressed this phenomenon in his study of the nature of folklore, where he divided the question of authorship in folklore by a time factor. Folklore of the first kind, or pure folklore, which comes to us from prehistoric times, whose versions are widespread throughout the world and spread through word-of-mouth transmission, has no authorship. Whereas the second kind of folklore, is that of literary origin. This is, a creation liked and accepted by the people, which is also transmitted orally, but that its origin is recognized by a literary creation. Such creation is also called folklore, but the author is known (Propp, 1984, 9). This fact, evidenced by Propp, extends the definition of folklore by acknowledging the authorial element as well as the feature of writing. Such developments which were influenced by the advances and dynamics of the development of human society, which came as a result of industrialization, technological developments and social movements, but which in 
turn were direct inflows of "folk wisdom", researchers have faced the dilemma of "where to get them place?" They have created new categories and subdivisions of the discipline, with the aim of incorporating new folk productions into the domain of folklore. Walter Ong did the same thing, given that his preoccupation was the process of transmitting from oral to written and the relation they had to the world of technology, as well as their effects from one to the other. He recognized this orality which was created in the time of modern technology as a secondary orality. This is this orality of the telephone, of the radio, the television which without writing and typing cannot exist (Ong, 2002, 2). Today the same can be said about folklore that continues to be present in social networks, where oral communication with all its expressive features is there, the same as always, except that it has changed the medium and expressive form (Dushi, 2015, 7-29). Now It has become digital (derived from Latin in the meaning of "digit-finger") and it is spread over the Internet. Even American folklorist Simon Bronner claims that the Internet acts folklorically: "Folklore as an expression of tradition has to be present on the Internet because it has become the primary way people "message", "connect" and "link" (if not talk) to one another; hence the Internet incorporates the symbolic and projective functions that folklore distinctively provides" (Bronner, 2011, 402). In such circumstances, the definition given by Sims and Stephens makes sense and can be reasonably accepted.

Folklore, regardless whether it is expressed, narrated, sung, transmitted, evidenced, or written, in whatever form it has reached us, among other things, is considered heritage, memory, and evidence of a retrospective assessment of the past, but also it is a reflection of the present and a reflection of ourselves. Viewing folklore as a memory, be it collective, social or cultural, gives the opportunity to give light to its other sides, thus making it a valuable material for memory studies. Analyzing and treating folk songs of the heroes and events that took place, from the point of view of historical events, but also of the national features and human relations in them, will enable us to identify and understand many facts about history, as well as to know ourselves by constructing our identity in the past. The combination of historical studies and oral tradition, under the prism of memory studies, brings new results and gives a different look to this material from the past. Oral traditions have served as banks of memory, where for centuries past events have been preserved and cultivated. According to the concept of Maurice Halbwachs, unlike history which, through the inclusion and synthesis of facts, aims to compile memory for the general past, collective memory implies the memory of the group and it is seen internally during a period that does not exceed, and is often shorter than the average duration of a human life (Halbwachs, 1980, 83-87). Consequently, a ballad or a folk song can easily serve as a collective memory.

Author David Rubin, who deals with the cognitive psychology of oral traditions in memory, says: "Songs, narratives and verses have been stored in a consistent form in memory for centuries without having to be written while an observer today finds it difficult to remember what happened yesterday, unless he takes notes" (Rubin, 1995, 3). Through unraveling the oral heritage from the past, with the methods of social and cultural anthropology, we can build the social, class, family, national identity of a community, but also of a society and its people. 
Thus, as the boundaries of the discipline of folklore expanded, this category of narratives found a place in folklore by the term personal narrative. This genre also finds its theoretic structure in the work of American folklorist Sandra Dolby Stahl on oral personal narrative as an oral/literary genre (Dolby Stahl, 1989). She previously addressed many theorists' dilemmas and disagreements about whether or not to accept this particular genre, while also presented clearly and arguably features of the personal narrative. The features that characterize this type of literary folklore, according to her, are: 1 . the dramatic structure of the story; 2 . the logical implicit search that the story is true, and 3. the same identity of the storyteller and the main character of the narrative (Ich-Bericht Form) (Dolby Stahl, 1989, 15). The indirect presence of tradition, expressed through the narrators' beliefs, ideas, and concepts, which are unavoidable during personal narrative even in the form of recollections of legacies inherited from ancestors, was also acceptable in the settings she gave to this type of narrative (Dushi, 2009, 100).

\section{Oral narratives in folkloristics and history: differences and similarities in their approach and methodology}

Narration is the first feature that characterizes this kind, whether it is a testimony or an oral prose. Past experiences stimulate this kind of narrative. That is why even the term known in the world today - Oral history - implies linking the oral and the past; narration and the memory; folklore and the history.

This intercession, which is often accepted as a research method, brings closer to many points, the folklorist and the historian. But it is their different viewpoint on the same oral source that differentiates the concepts of the folklorist and of the historian. American folklorist Richard Dorson, in his essay on the roles of oral historians and folklorists, distinguishes their method at work: "Before comparing notes from interview techniques and archiving systems, the oral historian and the folklorist must bear in mind their great divergences in methods and in concepts (...) The folklorist collects (stories) and the historian interviews" (Dorson, 1986, 284). It is obvious that while the folklorist allows the narrator to express emotion, fantasy flow, and creativity in the story, the historian seeks to extract the dates and the factual side of the narrator by dividing the story into pieces of history interviews. The folklorist is interested in anyone's narrative and oral creation, while the historian seeks to interview certain witnesses. Oral narratives, more than facts, show the narrator's emotion, imagination, fantasy and creativity, which are not very important to the historian, but to the folklorist they are. The oral historian is not interested in the facts but rather to the truth behind the facts, as Portelli said. He is also interested not only in what it is said but also in what hasn't been said. Moreover, he continues, the specific usefulness of oral resources for an oral historian is, not so much in the ability to preserve the past as in the work that memory has done to change it (Portelli, 2003, 63- 74).

Oral history is, in fact, the emotional side of history. Personal history means a subject for the oral historian, but not for the historian, nor for the writer of general history. Even Portelli, for these evidences from personal experience, which might divert the historical fact, says that if they can be historically incorrect, they still 
remain 'psychologically' true, because as such, they provide important evidence to the oral historian, respectfully to the folklorist (Portelli, 2003, 68). The oral history sources require multiple proofs by the historian in order for these to become historical facts, but for the folklorist there is no need for the verification of these "facts". The fantasy, the imagination allowed by folklore, risks to distort the facts of history. As Alistair Thomson writes:

In England, despite initial links, oral history and folklore studies tended to travel different paths; Paul Thompson argues that English folklore studies "never escaped from the stigma of amateurism" (Thompson, The Voice of the Past, 71-2). While the nationalist politics of Britain's Celtic nations - Wales, Scotland and Northern Ireland - have forged closer relationships between folklore studies and oral history, and in Scandinavia folklore studies has had a profound impact upon the development of oral history, studies of memory and 'oral tradition' in non-Western societies and indigenous cultures have also made important contributions to our understanding of the nature and meaning of oral history accounts

(Thompson, 2006, 53).

Therefore, to justify this idea we refer to the thoughts of historian Jan Vansina, who in his appreciation of oral traditions as sources for history states:

Oral traditions are the historical sources of a special nature. Their special nature derives from the fact that they are "unwritten" sources couched in a form suitable for oral transmission, and their preservation depends on the powers of memory of successive generation of human beings. These special features pose a problem for the historian. (...) Oral tradition is not necessarily untrustworthy as a historical source, but, on the contrary, merits a certain amount of credence within certain limits

(Vansina, 1996, 122).

Oral history being related to the personal story expresses the narrator's personal views on a particular event or experience, so as such it is also a personal source, not necessarily credible to the historian. However, the choice of this source itself is the personal decision of the historian. Such a source is accepted a priori, without verification of its historical and factual truth, and thus, can be nothing more than folklore. The professionist who writes history must be guided by the historical truth, the proven fact and the document. The historian must be guided by authenticity, objectivity, which is also the basic scientific feature of making history. The historian writes general history, referring to many written sources such as documents, interviews, reports, articles, newspapers, diaries, and letters. First the collection of sources, then their analysis, and finally his position as the third stage of the work, presents the work of the historian, says British historian Edward Hallett Carr, in his book What is History? He claims that the role of the historian is crucial on distinguishing the facts of history from the other facts about the past (Carr, 1961, 
10). Such a concept, essential to the historian's inclination to unravel historical facts, will certainly distinguish the historian from the folklorist. His tendency towards objectivity, unlike the folklorist who tends toward subjectivity, is in fact what makes these researchers different, respectively and different in their approach to oral sources.

Oral history, as a method started by folklorists, is finding application in many fields today. As the English oral historian Lyn Abrams, author of the wellknown book Oral History Theory claims:

Oral history was partly preceded by the European tradition of folklore and ethnology recordings, which had always privileged the spoken voice as a repository of tradition, and then by the emergence of social history and historical sociology which employed oral history as a means of rescuing the voices of the laboring people

(Abrams, 2010, 40).

Changes in the field when harmonized with changes in academia enable or facilitate the analytic decomposition of social phenomena. In fact, it is the new technical and technological developments that together with media are offering new creative possibilities, towards giving opportunity for personal versus collective creation. These new trends today are testing many of the characteristic features of social disciplines, pushing and expanding research beyond the old research field. The attributes of folklore today must be adapted according to production in the fieldwork. If we want for folklore to advance further, we need to move towards updating folklore attributes by adapting them to social reality because otherwise we risk of putting folklore in the museum. On the other hand, the advancement of the methods of searching for history has brought the historian to the field, out of archives, where he has to interview live witnesses in order to supplement the factual side of the evidence from the archives.

The paradigms of these two sciences (folklore and history) today are moving in the direction of their approach. The opportunity to give voice to the silent people (ex.: to the group of people who were marginalized in society and as consequence their voices were not heard), by recording their oral narratives, respectively their memory, by the method of oral history, is providing more and more material to the general history itself, as well as providing new sources to the folkloristics. The combination of disciplines makes easy finding of solutions for different problems, while simultaneously influencing the advancement of disciplines. As in this case the advancement of the research methods of history story has brought the historian to the field, out of the archive, where he has to interview live witnesses and narrators in order to supplement the factual side of the evidence from the archives. Whilst on the other hand folklorist has approached the real events that have taken place, not always seeking for the fantastic and unreal stories, in order to find the answer to the real spiritual phenomena that happen to oral culture and memory of the society. The intersections of these two disciplines, folklore and oral history, are indicative that interdisciplinarity is an immanent need for the existence of folklore in the face of challenges to new perspectives. 


\section{LITERATURE}

ABRAMS, L. (2010). Oral History Theory. London: Routledge.

BEN-AMOS, D. (1971). Toward a Definition of Folklore in Context. The Journal of American Folklore, 84. (331), 3-15. [Accesed: 15 January, 2020].

BEN-AMOS, D. (1983). The Idea of Folklore: An Essay. Studies in Aggadah and Jewish Folklore. Jerusalem: The Magnes Press.

https://www.sas.upenn.edu/folklore/faculty/dbamos/TIOF.html [Accesed: 15 January 2020].

BLANK, T. J. (ed.) (2009). Folklore and the Internet. Utah: Utah State University Press.

BRONNER, S. J. (2011). Explaining Traditions - Folk Behaviour in Modern Culture. Kentucky: The University Press of Kentucky.

CARR, E. H. (1961). What is History? London: Penguin.

DOLBY STAHL, S. (1989). Literary Folkloristics and the Personal Narrative. Bloomington: Indiana University Press.

DORSON, R. (1996). The Oral Historian and the Folklorist. Oral History: An Interdisiplinary Anthology. Plymouth: Alta Mira Press, 283-291.

DUSHI, A. (2009). Homo Narrans: Rrëfimi personal gojor. Prishtinë: Instituti Albanologjik.

DUSHI, A. (2015). Folklori ndërmjet mbijetesës dhe transformimit, Java $e$ Albanologjisë 5, 2014 Prishtinë: Instituti Albanologjik, pgs. 7-29.

DUSHI, A. (2015). Personalia in Folklore: Oral personal narrative as a folkloristic sub-genre. Balkan Culture seen through the Folkloristic and Ethnological Researches. Skopje: Institut za folklor "Marko Cepenkov", 91-98.

GOLEŽ KAUČIČ, M. (ed.) (2017). Introduction. What to do with Folklore? Trier: WVT Wissenschaftlicher Verlag Trier. 5-8

HAKAMIES, P. (2003). Oral History - A new paradigm in Finnish Folkloristics. ЕТНІЧНА ІСТОРІЯ НАРОДІВ СВРОПИ, 6-9.

www. irbis-nbuv.gov.ua > cgi-bin > irbis nbuv > cgiirbis 64 > eine 2003143

[Accesed: 23 November 2019].

HALBWACHS, M. (1980). The Collective Memory. New York: Harper Colophon Books.

HEIMO, A. (2001). Untold stories, twice told tales: How people narrate their own stories. In: KAIVOLA-BREGENHOJ A. \& W. KNUTS U. (eds.) Pathways: Aproaches to the Study and Teaching of Folklore. Turku, NNF Publication 9.

ONG, W. J. (2002). Orality and Literacy: The Technologizing of the Word. London: Routledge.

PORTELLI, A. (2003). What makes oral history different. In: PERKS R. \& THOMSON A. (eds.) The oral history reader. London: Routledge, 63-74.

PROPP, V. (1984). Theory and History of Folklore. Minneapolis: University of Minnesota Press.

RUBIN, D. (1995). Memory in Oral Tradition - The Cognitive Psychology of Epic, Ballads, and Counting-out Rhymes. New York, Oxford: Oxford University Press. 
SIMS, M. \& STEPHENS, M. (2005). Living Folklore: An Introduction to the Study of People and Their Traditions. Logan: Utah State University Press.

THOMPSON, A. (2006). Four Paradigm Transformations. The Oral History Review, vol. 34, Issue 1. London: IOHA, 2006, 49-70.

VANSINA, J. (1996). Oral Tradition and Historical Methodology. In: DUNAWAY \& BAUM (eds.) Oral History an Interdisciplinary Anthology. Playmouth: Alta Mira Press, 121-142.

Арбнора Души

\title{
ПРЕДИЗВИКОТ НА ДЕФИНИРАЊЕТО НА ФОЛКЛОРИСТИКАТА КАКО ДИСЦИПЛИНА (ВРСКИ МЕЃУ ФОЛКЛОРИСТИКАТА И УСНАТА ИСТОРИЈА)
}

\author{
Резиме
}

Фолклористите ширум светот веќе два века се обидуваат да ги дефинираат границите на фолклористиката како дисциплина, меѓутоа и покрај сите нивни напори, никогаш не се дојде до конечно решение. Постојат фолклористи што се откажаа од овој потфат (како Елиот Оринг), кои сметаат дека не постои потреба од дефиниција за фолклористиката. Сепак, постојат многубројни меѓународни фолклористи, кои се обидоа одново да го дефинираат фолклорот, земајќи ги предвид новите текови и предизвици со кои се соочи фолклористиката како дисциплина. Не треба да се заборави дека многу дисциплини се изродени од фолклористиката и се развија во различни, други насоки, со што се фрли ново светло врз предметот што го истражува фолклористиката.

Се обидов, во својот труд, да ја согледам врската меѓу фолклористиката и усната историја, како две дисциплини, кои се испреплетуваат заемно, но сепак се разликуваат по однос на концептот и методологијата на истражување. Се насочив на заемните места меѓу фолклорот и историјата, како и на сличностите и разликите меѓу овие две дисциплини.

Предметот на истражување често го приближува фолклорот до усната историја, но пристапот и методологијата се разликуваат кога пристапуваат подлабоко кон истражената материја. Заклучокот на мојот труд упатува токму на разликите меѓу фолклористиката и усната историја, преку ползување на издадени меѓународни студии, како и на истражувачка работа на терен, во последните неколку децении. 